DOI https://doi.org/10.18551/rjoas.2018-11.22

\title{
THE DYNAMICS OF POLITICAL MARKETING IN THE WINNING STRATEGY OF POLITICAL PARTIES IN INDONESIA
}

\author{
Triono*, PhD student \\ Political Studies, Faculty of Social and Political Sciences, Padjadjaran University, Indonesia
}

Kartini D.S., Sulaeman A.

Faculty of Social and Political Sciences, Padjadjaran University, Indonesia

*E-mail: triono.sr@gmail.com

\begin{abstract}
The politic competition in the general election in the state that embraces the democracy political system like in Indonesia poses a challenge for political parties to do innovations and formulate strategies in order to political winning. The political winning strategy is performed as a part of political marketing and political campaign efforts to public. The objective of political marketing is that in order to the political programs and policies as parts of political party products can be accepted by public. The dynamics of political marketing development and political strategies make political parties make efforts to improve resources they have to be more maximum to run in the political works. There are many factors that make political parties survive in each political competition. Therefore, political marketing management as parts of political winning strategy efforts becomes important for political parties.
\end{abstract}

\section{KEY WORDS}

Political party, political marketing, democracy, general election.

Political strategy management is important for a political party in the political competition winning against other political parties, or directly by candidates of legislative members or candidates or regional heads who want power and influence from public. As a pillar of democracy system, the existence of political party becomes a distinctive magnet for academic study and public discussion. Political dynamics and political challenges continue to develop and demand political parties to perform innovations in formulating political winning strategies. This is because the formulation and execution of strategies can influence either success or failure of political strategy (Adrianus et.al, 2006: p. 196). The existence of political party is a must in the modern and democratic political life (Amal, 2007).

Therefore, the management of political winning strategy becomes important in the efforts to gain votes and political party position in every election contest. Effectiveness in empowering resources owned by a political party to be an indicator for either success or failure of designed and implemented political strategy processes. This is shown by public opinion that continue to build so that this shall be able to increase a candidate and political party popularities to be familiar for public as constituents (Chandrappa, 2014). Easton (1965: p.122-123) in his system theory states that political parties are one of regulators of demands for their mass.

According to Igor D. (2013: p.31), in developed countries, the implementation of marketing has been expanding beyond of business institutions. Marketing experts are very involved in competing to gain political power. The assumption is that the marketing concept can be run and provide benefits in political world. Nowadays, it can be said that anyone shall need marketing discipline. Political marketing offers a concept to politicians to be effectively able to make political products, political segmentations, political positioning, political communication, and the political marketing is a method and a concept of marketing application in the context of politics sciences.

The concept and model of political marketing is increasingly developing along with the demands of time and political situation. Some political marketing models are models by 
Newman (1994); O'Cass (1996); J. Less-Marshment (2001); Schroeder (2003); Ormrod's (2005); Nursal (2004); and Robinson (2005). Less-Marshment (2009: p.13), for example, divides orientation of political parties in their political marketing strategies into three; product oriented party (POP), sales oriented party (SOP), and market oriented party (MOP). As one of political marketing models, Less-Marshment states that the POP-SOP-MOP marketing political model as segmentation of political party is not absolutely able to apply fully in a political system embraced by a country, because of different geographical climate conditions and political systems in a country.

In the practice, the political marketing strategy is not always oriented to a final result where a political party gains high votes in a general election. However, it is rather to keep the constituent trust (voters) to stay voting a political party or a candidate nominated by a political party (Firmanzah, 2008). The role of political marketing is not limited to make voters for a particular political party or candidate in an election, but also to build cadre and constituent loyalties in the future.

The political winning strategy formulation to embrace public sympathy in each political constellation, as it is stated by J. Less-Marshment (2001: p.75), shall always be sought and formulated by a political party as a part of strategy in political winning. Nominating candidates and political programs that are reflected in the political policies become benchmark and assessment toward a political party performance. By political products offered by a political party to public, the public shall assess the quality and principle of making cause of a political party to public interests.

A political party winning strategy that is packed in the political marketing is more and more required to keep a political party sustainability in the future. It is proper that Schweiger \& Adami (in Newman, 1999: p.83) suggests that current politics inclination is the evolution from prior politics, where the most capable political party to manage internal and external dynamics should relatively survive.

In the political marketing model by Less-Marshment (2009), the POP-SOP-MOP approach can be seen in the phases and stages how political products are built as efforts of political marketing strategy. Stages built with POP- SOP-MOP become the characteristics of existence of a political party in the different public segmentations and dimensions. In the SOP and POP models, the political party characteristics are shown by orientations of political party products that only focus to the political party itself. A political party with this kinds of models tends to refuse changes for its political products and does not see from the public perspective as part of its voters.

Since reformation era in 1998, the political development in Indonesia is far better in the democracy enforcement and freedom of political rights of citizens compared to political conditions in the previous era. This was indicated by the births of many political parties and they have been becoming contestants in Indonesia general election. In reformation era, there were 141 new political parties in Indonesia (Huesin, 2014: p.125). One of new parties born is reformation era was Justice Party (Partai Keadilan - PK). As a new comer, PK had provided different political nuance in the political party system in Indonesia. This party was born from movements of youth and campus activists (Rahmat, 2008: p.7).

In its journey, PK showed it identity as a party that developed democratization process in its internal of party. When looking at the history and platform of political party policy, PK had relative characteristics that were almost similar other similar parties in the world such as: Adalet Ve Kalkinma Partisi (AKP) in Turkey, FJP party in Egypt, An Nahdhah Party in Tunisia, PAS party in Malaysia, Front Islamic du Salut (FIS) party in Aljazair, Hamas party in Palestine, in other parties in other Middle East countries. This similarity could be seen from the political ideology source as the struggling spirit and movement of the politics.

Amir (2003) suggests that characteristics attributed to Islamic political parties are the use of Islamic symbols and Islamic basic of mass in their movements. Prosperous Justice Party (Partai keadilan Sejahtera - PKS), the next evolution of PK party, uses Islam as the party ideology by bringing values of Islamic missionary endeavor in its movement. The dynamics and events in internal of PKS party become interesting matters to study especially dynamics in life of political democracy in Indonesia. The existence and electability of PKS as 
a political entity has really been tested with varying political issues and events. These political events are indeed parts of solidity of PKS cadres and the party sustainability in the politic stage in Indonesia.

Developing dynamics in internal of PKS party show solidity of internal of PKS party and autonomy of PKS cadres that become a system of solidarity in strengthening basic of party institution and its movements (Herdiansah, 2016). The PKS presence in the political stage in Indonesia that brings Islam as basic of party ideology becomes a new color in the Indonesia political development and becomes political market amongst youngsters.

The PKS cadre presence in the leadership of regional head becomes a proof that PKS has a position in public. The relationship with other political parties is also shown by PKS by cooperating in a political coalition in efforts of advancement of a region. PKS always has bargaining value in each moment of regional head election in Indonesia. This reality gives an illustration that there is an interesting matter from PKS in the party management and strategy of political marketing management in its internal of party. Polemics and political events afflicting PKS had been able to manage properly and this makes PKS to be more taken into account its credibility by other political parties.

In Lampung context, PKS has been presence since 1998 as a part of political entities in Lampung province. The PKS existence used to be having bargaining position in each political event in Lampung. It was recorded that from election 1999 to election 2014, the vote gains of PKS in Lampung increased. In the legislative election 2009, PKS in Lampung for Regional House of Representative level in Lampung province gained 302,835 voters with 7 chairs in regional parliament (Lampung Committee of General Election, 2017). The problem to study in this research was how did the PKS political marketing strategy in the efforts of winning legislative election 2009 in Lampung province and what factors were becoming obstacles in the political winning process.

\section{METHODS OF RESEARCH}

In the politics science study, according to Marsh and Stoker (2011: p.240), qualitative method plays a main role starting from individual to group researches in the formal politic stage, to public attitude and behavior such as behavior of voting. Therefore, data and arguments to build in this paper used qualitative study method, by collecting varying scientific reference sources from primary source by using interviews to research informants and secondary source by tracking back related writings such as journals, papers, mass media news concerning political marketing of political party.

Another objective in using qualitative design is to understand the analysis work frame based on the occurring reality concerning the political marketing essence of a political party in winning election. Cresswell (2010) and Howard Lune \& Bruce L. Berg (1998) suggest that qualitative method is performed as a process where a researcher tries to build a holistic description upon observed problems or issues, so this shall require varying perspectives, and require identification on the factors involved in particular situations.

The researcher used data analysis technique containing of three paths of activities occurring in the same time; they were data reduction, data presentation and conclusion drawing or verification (Miles and Huberman, 1992: p.16-21). Data analysis was performed by using descriptive analysis by reviewing dynamics of political marketing strategy of PKS in Lampung in legislative election 2009 and factors becoming obstacles in the political winning process.

\section{RESULTS AND DISCUSSION}

Winning strategy is one of elements taking roles in determining and influencing political party success in the politics contest both in general election and regional head election performed by political parties. In this case the political party is demanded to do political planning and strategies to gain winning. Political winning strategy is performed as a part of political marketing process and political campaign to public. The objective is in order 
to the programs and political policies as political products of a political party can be accepted by public.

Based findings in the field, the researcher suggests that as efforts in the PKS winning strategy in general election and regional head election, the social network development that is developed by PKS can be classified into 5 (five) models. First, education model of party cadres who are responsible for controlling and possessing mission to promote supporting organ for party from students, traders and academicians. In this model level, the researcher sees that PKS is success enough in getting big influences through educations in Islamic studies in campuses and group of Islamic studies to academicians and traders, and PKS struggling values can be delivered to public.

The second model, political recruitment from public in common with and objective that PKS can recruit potential cadres who are going to have public positions and who have high militancy in developing the party ideology. The researcher in this case sees that, as party cadres who had social networks in public, legislative candidates from PKS during general election 2009 both nationally and regionally in Lampung were dominantly occupied by internal cadres who their regeneration careers were proper to present to public as candidates of members of legislatives. The cadres as result of PKS cadre development had underwent long processes in their regeneration careers in internal of PKS, so that no wonder if the main strength of PKS lied on their militant cadre movements.

Third, social activity organization model by holding open activities for public, with an objective to build social networks with public so that public recognize and being convinced with the products informed by PKS.

Fourth, public imaging model by utilizing formal political channels that are supported by party regeneration system. This model is performed by using supporting media as a part of political campaign and education to public. In this pattern PKS makes efforts to disseminate images in better ways concerning campaign truth or responding negative issues about PKS.

Fifth, model of political communication through media networks. In this model PKS emphasizes the roles of media as political communication means and political strategy to public.

The party of democracy in general election 2009 became a political year with a high political competition, because numbers of political parties joining the legislative general election 2009 increased significantly compared to legislative general election 2014. In another side, referring to Hasto's (2016) statement, general election 2009 was an era for electoral parties, and this could be seen from the design of political party that was only becoming a means to mobilize votes to win the election by ways that emphasized political communication, imaging, and media strength support. According to Hasto, in this era, the party ideological characteristic was more becoming to cease and was transformed into a "catch-all party" characteristic.

Seeing the 44 political parties joining legislative general election 2009, it provided a description how tight the competition in the legislative general election 2009. Only political parties who were ready in terms of resources and political strategies in winning the election that succeeded to position their cadres in the legislative both nationally and regionally. Winning strategy becomes urgent and is required by each political party to survive in each general or regional head election event.

Another thing in general election 2009, it was an election by using proportional representative with an open list of candidates system to vote members of House of Representative, provincial Regional House of Representative, and district/municipal Regional House of Representative. Parliament chair won by each of political party reflected a proportion of total votes that each political party obtained. The mechanism of this system provided a big role for voters to determine their representatives that were going to have chairs in the House of Representative. The elected candidates were whose votes were the most. The voting for members of Regional Representative Board (DPD) was performed by a system of district with the most representative. District system applied in provincial level, 
where each province would have 4 (four) representatives having chairs in the Regional Representative Board (DPD).

The political competition in legislative general election 2009 forced political parties to do political strategy scenarios that were able to gain public votes. This made both older and new political parties competed to gain votes. This competition amongst political parties brought up both healthy and unhealthy competitions such as propaganda wars by claiming their merits to public and giving pseudo political promises to public.

In legislative general election 2009, PKS gained 8,204,946 (7.88\%) with 57 chairs in House of Representative of Republic of Indonesia. This votes gain increased numbers of chairs in parliament compared to result of legislative general election 2014 (45 chairs), however the votes gain decreased into 8,325,020 (7.34\%) in legislative general election 2014. PKS in Lampung gained 7 chairs in Regional House of Representative in Lampung with 302,835 votes gain.

Many factors causing PKS votes gain in legislative general election 2009 did not meet target both nationally and regionally. Whereas, the PKS target in legislative general election 2009 was becoming one of three biggest national political parties with a target of 20 million voters. PKS political communication strategy was not he only determining variable for votes gain improvement in legislative general election 2009 if it was compared to previous general elections. However, the pattern of communication strategy implementation by PKS in legislative general election 2009 took role in determining PKS success in winning the election, because any political strategy should function as connecting bridge between objectives and political marketing of political party to obtained result. Winning strategy became a kind of political party contest of power in keeping and/or expanding network of mass of their voters.

Referring to notion of Schroeder (2009), the political strategy performed by PKS is a part of offensive and defensive strategy process in politic. This strategy is used in order to maintain the basic of voters in constituent region as well as a part of strategy to expand voter network to vote the political party. According to Firmansyah (2008), the fundamental problem for political parties is how to collect, manage, and use resources they own efficiently and effectively to support their political strategies. This becomes homework for political parties in Indonesia; how to proper formulate political strategies to be implemented in their political products.

Based on research result in the field, and by lying on political marketing theory by LessMarshment (2009) concerning models of product oriented party (POP), sales oriented party (SOP), and market oriented party (MOP) as the base of analysis in this research, Less explains stages in POP-SOP-MOP model that are relatively similar: (1) product design stage, (2) communication stage. (3) campaign stage, (4) general election implementation stage, (5) handover stage, (6) market research stage, (7) adjustment stage, and (8) political promise implementation stage.

The political marketing of MOP model is more prominent in PKS characteristic as a political party that emphasizes political research in formulating political products and programs that become policies of PKS in Lampung. The political product design, political communication pattern, campaign strategy and implementation of political promises as stated by Less-Marshment (2009) in political marketing stages by PKS in Lampung are built based on political research performed internally by PKS in Lampung. This political research became a political umbrella for PKS in formulating its political strategies in winning legislative general election 2009.

In the researcher's perspective, the political marketing model of Less-Marshment (2009) can be added with political evaluation stage in the political marketing process. The political evaluation is analysis and assessment processes performed by a political party to effectiveness of political strategy that is used in obtaining its political objectives. The political evaluation becomes important as a political party stage in evaluating political party policy and program that are related to public interests (the constituent). In addition, the political evaluation becomes important in the organization improvement process of the political party. In this case, a classification about the position of political marketing strategy from political 
parties in Indonesia may be made. The main objective is to find out the orientations of political parties in implementing their visions, missions, and strategies for political winning.

Factors becoming obstacles in the political winning process of PKS in Lampung in legislative general election 2009 include: minimum political financial capital, exclusive stigma that is attributed to PKS, and public pragmatic and apathetic conditions toward political parties. Public often judge that PKS is different amongst other groups with exclusive movements that PKS brings up by its cadres, where internal solidity is not followed by solidity with social and public. This does not make public interest immediately take role in each activity conducted by PKS.

\section{CONCLUSION}

The PKS existence in Lampung shows cadres' independences from both national and regional figures. The political marketing strategy with models of product oriented party (POP), sales oriented party (SOP), and market oriented party (MOP) by PKS in Lampung in its efforts to win the legislative general election 2009 was performed with strategies of political imaging, political figures, permanent campaign, local politic culture, social networks, mass media, and public services. MOP model mostly dominated the characteristic of political marketing performed by PKS in Lampung, because in formulating its political product and policy, PKS in Lampung always relied on political research result from internal and external of PKS.

Unachieved national votes target in the legislative general election 2009 was caused by come factors and obstacles the PKS faced. However, the political dynamics and formulation of political marketing performed by PKS in Lampung showed that political party management that was built by PKS had run properly. Taglines of "clean, concern, professional" as PKS political products were able to make cadre militancy of PKS in Lampung to possess stimulants and strength in driving political party machine as efforts in political winning strategy.

\section{REFERENCES}

1. Amal, Ichlasul. (2007). Teori-teori Mutahir Partai Politik. Yogyakarta: PT Tiara Wacana.

2. Amir, Zainal Abdidin. (2003). Peta Politik Islam Pasca Soeharto. Jakarta: LP3ES.

3. Andrianus, Toni Pito dkk, . (2006). Mengenal Teori-Teori Politik dari Sistem Politik sampai Korupsi. Bandung: Penerbit Nusantara.

4. Chandrappa, K. (2014). The Influence of the Media in Politics-Campaigns and Elections. 3 (12), 2310-2312.

5. Creswell, John W. (2010). Research Design: Qualitative, Quantitave, Quantitative and Mixed Methods Approaches, London: Sage Publication.

6. Dirgantara, Igor. (2013). Strategi Political Marketing. dalam https://igordirgantara.wordpress.com/2013/06/05/3620/ [5/1/16]

7. Easton, David. (1965). A Framework for Political Analysis. Toronto: The Prentice Hall of Canada.

8. Firmanzah. (2008). Mengelola Partai Politik; Komunikasi dan Positioning Ideologi Politik di Era Demokrasi. Jakarta: Yayasan Obor Indonesia.

9. Herdiansah, Ari Ganjar. (2016). Rasionalitas PKS; Berdemokrasi ala Tarbiyah. Bandung: Unpad Press.

10. Husein, Harun. (2014). Pemilu Indonesia: Fakta, Angka, Analisis, dan Studi Banding. Jakarta: Perludem.

11. Kristiyanto, Hasto. (2016). Dinamika Koalisi Partai Politik di Tingkat Parlemen. Bahan Kuliah Umum Pascasarjana Prodi IImu Politik FISIP Universitas Padjadjaran. Bandung, 15 Februari 2016.

12. Lees-Marshment, Jennifer. (2001). Political Marketing and British Political Parties: The Party's Just Begun. Manchester: Manchester University Press. 
13. Lees-Marshment, Jennifer. (2009). Political Marketing: Principles and Applications. London: Routledge.

14. Lees-Marshment, Jennifer. (2009). Political Marketing and the 2008 New Zealand Election: A Comparative Perspective. Australian Journal of Political Science. 44 (3) pp. 457-475.

15. Lees-Marshment, Jennifer, et.al. (2010). Global Political Marketing. Routledge 2 Park Square, Milton Park, Abingdon, Oxon, OX14 4RN.

16. Lune, Howard \& Berg, Bruce L. (1998). Qualitative Research Methods for the Social Sciences. England: Pearson.

17. Marsh, David., dan Gerry Stoker. (2011). Teori dan Metode dalam Ilmu Politik. Bandung: Nusa Media.

18. Miles. M. B. \& Huberman, A. M. (1984). Qualitative Data Analysis, A Sourcebook of New Methods. London, New Delhi: Sage Publications, Beverly Hills.

19. Newman, Bruce,. I. (1999). Handbook of Political Marketing. California: Sage Publication.

20. Nursal, Adman. (2004). Political Marketing: Strategi Memenangkan Pemilu Sebuah Pendekatan Baru Kampanye Pemilihan DPR, DPD, Presiden. Jakarta: PT. Gramedia Pustaka Utama.

21. O'cass, Aron. (1996). Political Marketing and the Marketing Concept. Europan Journal of Marketing. Vol. 30 No.10/11, pp 37.

22. Rahmat, M. Imdadun. (2008). Ideologi Politik PKS; Dari Masjid Kampus ke Gedung Parlemen. Yogyakarta: LKiS.

23. Schroeder, Roger G. (2003). 2nd Edition. Operations Management: Contemporary Concepts and Cases. McGraw-Hill International Edition.

24. Schroeder, Peter. (2010). Strategi Politik. Jakarta: Friedrich-Naumann-Stiftung Fue die Freiheit.

25. Ware, Alan. (1995). Political Parties and Party System. New York: Oxford University Press Inc. 